\title{
Developmental trajectories of school-beginner's ability self-concept, intrinsic value, and performance in mathematics
}

\author{
Markku Niemivirta1,2 iD 0000-0001-7152-5152 \\ Anna Tapola2 ${ }^{\text {iD } 0000-0003-0442-2051 ~}$ \\ Heta Tuominen 1 (iD 0000-0002-5629-375X \\ Jaana Viljaranta1 ${ }^{1}$ 0000-0001-6169-4008 \\ 1 University of Eastern Finland, Finland \\ 2 University of Helsinki, Finland
}

\begin{abstract}
Author Note
Correspondence concerning this article should be addressed to Markku Niemivirta, School of Applied Educational Science and Teacher Education, University of Eastern Finland, P. O. Box 111, 80101 Joensuu, Finland. Tel. +358 50415 6703. Email: markku.niemivirta@uef.fi
\end{abstract}




\begin{abstract}

\section{Background}

Although research clearly evidences the importance of motivation in learning mathematics, fairly little is known about the developmental dynamics between the different facets of mathematics motivation and performance, especially during the early school years.
\end{abstract}

\begin{abstract}
Aims
In a longitudinal setting, we examined (1) how children's ability self-concept and intrinsic value in mathematics change over time during their first three years in school, (2) how those changes relate to each other, and (3) how they connect with mathematics performance.
\end{abstract}

\title{
Sample
}

The participants were 285 Finnish school-beginners (52.7 \% girls).

\section{Methods}

Latent growth curve modelling was used to examine the developmental trajectories of children's ability self-concept and intrinsic value, and how those trajectories predicted later mathematics achievement (both mathematics test performance and teacher-rated grades), while controlling for previous mathematics performance and gender.

\section{Results}

The results showed significant decrease in children's ability self-concept and intrinsic value, but also significant individual differences in the trajectories. The high dependency between the levels and changes in self-concept and intrinsic value led us to specify a factor-of-curves latent growth model, thus merging the trajectories of ability self-concept and intrinsic value into one common model. The subsequent results showed prior mathematics performance to predict change in children's mathematics motivation, and both the level and change in mathematics motivation to predict third-grade performance and teacher-rated grade.

\section{Conclusions}

Our findings evidence the developmental coupling of children's ability self-concept, intrinsic value, and achievement. Achievement seems to enhance mathematics motivation, and positive motivation appears to support the further development of mathematics skills.

Keywords: ability self-concept, intrinsic value, mathematics, development, elementary school 


\section{Developmental trajectories of school-beginner's ability self-concept, intrinsic value, and performance in mathematics}

\section{Introduction}

As several countries have witnessed a decline in mathematics performance over recent years (OECD, 2019), the concerns about this trend and the underlying reasons seem rather global, despite the idiosyncrasies of different educational systems. Finland is no exception here. Complementing this trend, representative national studies have further shown students' mathematics motivation (e.g., perceptions of one's competence and interest) to decrease not only over time, but also across different age cohorts (Metsämuuronen, 2013). To trace the sources of these changes and to consider their implications for teaching, we first need a better understanding of the dynamics between mathematics motivation and performance during the early school years. In the present study, we expand on previous findings on this theme by investigating how children's motivation in mathematics develops over time from the first to the third grade, and how that development is linked with children's mathematics performance. For this purpose, we draw on the expectancy-value approach to motivation.

\section{Expectancy-Value Framework}

The expectancy-value theory (EVT; Wigfield \& Eccles, 2000; for recent extensions, see Eccles \& Wigfield, 2020) is one of the most prominent approaches to the study of motivation, achievement, and educational choices. It focuses on two components of motivation that are likely predictors of students' commitment, engagement, and performance in academic settings: beliefs about one's ability in a certain domain, and the value ascribed to it. While a belief about one's ability is usually considered as a unidimensional construct, value beliefs can be divided into several facets such as intrinsic value (the enjoyment derived from an activity or interest in a task), attainment value (personal importance of succeeding in a task), and utility value (perceived usefulness of success in a task). Cost, in contrast, describes the perceived negative consequences of engaging in a task (e.g., missing other opportunities). In the long run, these motivational beliefs importantly shape students' choices of educational and career-related pathways (Simpkins et al., 2006; Viljaranta, Nurmi, et al., 2009; Watt, 2006; Watt et al., 2012). The expectancy-value framework has been extensively applied in studies linking mathematics 
motivation with both achievement and mathematics-related educational and occupational choices (Aunola et al., 2006; Lauermann et al., 2017; Lazarides et al., 2018; Watt et al., 2012), thus making it highly relevant for mathematics education (Schukajlow et al., 2017).

In this study, we use EVT as a theoretical umbrella under which we position related prior research and our own study. That is, although we focus on ability self-concept and intrinsic value as the two key aspects of expectancies and values, we draw more broadly on studies that represent considerable empirical overlap, despite the differences in theoretical nuances and the concepts employed (e.g., competence beliefs, ability judgments, or self-concepts, and intrinsic motivation, interest, or intrinsic value, respectively).

Ability self-concept refers to one's evaluation of current competence or ability in a certain subject area or learning content (Marsh et al., 2019; Wigfield et al., 2016), whereas intrinsic value represents the enjoyment attached to a certain learning content and gained from engaging with it (Eccles \& Wigfield, 1995; Gaspard et al., 2020). While the different facets of task values seem to become more clearly differentiated only until the upper elementary school years, the specificity of ability self-concepts and intrinsic values with respect to different school subjects seems evident already among school-beginners (Eccles et al., 1993; Wigfield, 1994).

\section{Mutual Connections and Changes in Self-Concept and Intrinsic Value}

Within the EVT, student's self-concepts and intrinsic value in a certain domain are postulated to be positively associated. Numerous cross-sectional studies across various gradelevels and school domains support this notion, and this coupling seems to be particularly strong in mathematics (Bong et al., 2012; Spinath \& Steinmayr, 2008; Trautwein et al., 2012). The average development of mathematics self-concept and intrinsic value also seems to follow a similar decreasing trend. Such a decline has been observed already from the early school years onwards, and compared to other school subjects, it seems to be especially pronounced in mathematics (Fredricks \& Eccles, 2002; Gaspard et al., 2020; Gottfried et al., 2007; Jacobs et al., 2002; Weidinger et al., 2017). The decline in self-concept may partly reflect natural developmental changes: younger students tend to have overly optimistic beliefs of their competencies, which then become more realistic due to students' cognitive maturation and increased social comparison (Fredricks \& Eccles, 2002; Stipek \& Iver, 1989). Decline in intrinsic value, in turn, might represent a self-protective function: when the learning contents become 
more difficult, and competition in the classroom context becomes more evident, lowering one's value could help to protect one's self-esteem (Fredricks \& Eccles, 2002).

Despite the concurrent dependencies and similar longitudinal changes, the mutual predictions between self-concept and intrinsic value in mathematics seem more complex. Some studies show positive effects from self-concept to intrinsic value or interest (Arens et al., 2019; Marsh et al., 2005; Viljaranta et al., 2014), while others report opposite predictions (Ganley \& Lubienski, 2016; Xu, 2018). Yet, in some studies these effects have been mixed, weak, or entirely absent (Pinxten et al., 2014; Spinath \& Steinmayr, 2008, 2012). The limited evidence available on the connections between the developmental trajectories of mathematics self-concept and intrinsic value suggests parallel changes over time. For example, Jacobs et al. (2002) found competence beliefs in mathematics to explain a substantial share of the changes in students' task values (interest, importance, and utility), and this effect to be especially pronounced during the early grades (see also Petersen \& Hyde, 2017). Studies examining similar connections during specific tasks have also shown changes in expectancy and interest to be strongly correlated (Niemivirta \& Tapola, 2007; Nuutila et al., 2021).

\section{Connections of Self-Concept and Intrinsic Value with Achievement}

In addition to their mutual relations, self-concept and intrinsic value also tend to go hand in hand with achievement. That is, students seem more likely to believe in their abilities and enjoy academic activities, if they at the same time succeed well in them (Denissen et al., 2007). This also is in line with the EVT, which argues that students' expectancies, values, and achievement develop in mutually reinforcing cycles (Wigfield \& Eccles, 2000). Accordingly, research has shown students' previous achievement to predict both competence beliefs (e.g., Arens et al., 2019; Helmke \& van Aken, 1995; Viljaranta et al., 2014) and intrinsic motivation in mathematics (e.g., Garon-Carrier et al., 2016; Viljaranta, Lerkkanen, et al., 2009), which, in turn, contribute to students' subsequent achievement. Intrinsic motivation has shown to predict mathematics achievement already during the first school years (Aunola et al., 2006; Gottfried, 1990), or even in preschool (Viljaranta, Lerkkanen, et al., 2009). Similarly, competence beliefs have been found to predict mathematics achievement relatively early on (Weidinger et al., 2018). Generally, however, the reciprocal relations with achievement seem more systematic and 
stronger for competence beliefs than for intrinsic value (Schneider et al., 2018; Weidinger et al., 2017; Xu, 2018).

Less is again known about how the developmental trajectories of self-concept and intrinsic value connect with achievement. Whether previous achievement predicts motivational trajectories seems to partially depend on the subject domain and the methodology employed. Regarding mathematics, some studies have shown prior achievement or aptitude to be linked with changes in mathematics-related expectancies and intrinsic motivation (Benden \& Lauermann, 2022; Gaspard et al., 2020; Gottfried et al., 2007), while some have failed to do so (Musu-Gillette et al., 2015). The predictions of trajectories of self-concept and intrinsic value on achievement and other academic outcomes such as course enrolment and career choices, instead, point out to the added value of positive (or less negative) motivational change over time (Ahmed et al., 2013; Gaspard et al., 2020; Gottfried et al., 2013; Musu-Gillette et al., 2015). Note, however, that the study designs and approaches to modelling change in these studies vary considerably, thus complicating the conclusions. For example, Gaspard et al. (2020) argued based on their analyses on different trajectory classes (i.e., groups of students with qualitatively different patterns of changes in ability self-concepts and intrinsic values) that besides the extent of motivational change in a subject domain, the effects on outcomes depend on the intraindividual hierarchies (i.e., relative levels) of ability self-concepts and intrinsic values across different domains. That is, the predictions of motivational changes in one domain may depend on the motivational changes in another domain.

Unfortunately, none of the above studies have looked at the developmental dynamics during the very first years of education. Design-wise closest to the present one is the study by Petersen and Hyde (2017), who investigated the developmental trajectories of mathematicsrelated ability self-concept, utility value, and interest in 5th, 7th, and 9th grades. Partly concurring with previous research, they found mathematics interest and utility value to decrease over time, while no change was observed in ability self-concept. Changes in self-concept and values correlated with each other, and changes in mathematics self-concept predicted mathematics performance five years later, even when controlling for prior performance. Neither interest nor utility value trajectories contributed to later performance. 


\section{Present Study}

Grounding on prior research we attempted to address some of the open issues through following research questions: (1) how do school-beginners' ability self-concept and intrinsic value in mathematics change from first to third grade, (2) how are changes in ability self-concept and intrinsic value related to each other, and (3) how do those changes predict later mathematics performance and achievement?

Based on previous studies, we expected both ability self-concept and intrinsic value to decline over time (Fredricks \& Eccles, 2002; Gaspard et al., 2020; Gottfried et al., 2001, 2007; Jacobs et al., 2002; Weidinger et al., 2017), and those changes to be correlated (Petersen \& Hyde, 2017). We also anticipated ability self-concept and intrinsic value to be related to mathematics performance, in terms of both the level (i.e., more positive self-concept and higher intrinsic value to be correlated with better performance) and change (i.e., more positive change in self-concept and intrinsic value to predict better later performance) (Denissen et al., 2007; Petersen \& Hyde, 2017; Schneider et al., 2018; Weidinger et al., 2018).

Since previous research has identified some relatively consistent gender differences in mathematics motivation (Ganley \& Lubienski, 2016; Jacobs et al., 2002), we also took this into account by including gender as a covariate. Although boys have shown to display stronger confidence in their mathematical abilities (Fredricks \& Eccles, 2002; Herbert \& Stipek, 2005) and higher intrinsic value (Frenzel et al., 2010; Lee \& Kim, 2014) than girls during the adolescent years, we did not expect such differences in the first grade (Viljaranta, Lerkkanen, et al., 2009). However, we did anticipate the possible change in self-concept favouring boys to become observable over time.

\section{Method}

\section{Participants and Procedure}

The participants were Finnish students ( $N=285 ; 52.7 \%$ girls) from 17 classes in seven schools in the metropolitan area in Finland. All participating schools were in middle-class, largely ethnically Finnish areas. A researcher visited the schools each spring during the first, second, and third grades to collect the data in group sessions during regular classes. In each session, the researcher first explained the children the procedure making sure the children understood the tasks and how to respond. The children then completed their sheets. 
Participation was voluntary, written consent was given by parents, and confidentiality was assured.

\section{Measures}

\section{Mathematics Ability Self-Concept and Intrinsic Value}

As the participants were first-graders (around seven years of age) in the beginning of the study, we could not expect them to read fluently. Therefore, all items were shown on a screen and read aloud. For responses, four smiley faces gradually changing from a sad to a happy face to represent the degree of agreement with the statement were used (see Appendix). The meaning and use of the scale was explained to the children with examples. Also, to keep the task as clear and straightforward as possible, we used simple indicators of our target constructs, derived from measures used in previous EVT studies (e.g., Eccles et al., 1993; Jacobs et al., 2002). Mathematics self-concept was measured with the question How good you think you are in mathematics?, whereas intrinsic value in mathematics was measured with two items representing two key aspects of intrinsic value, liking, How much do you like mathematics?, and enjoyment, How much do you enjoy being in math classes?. For the data analyses, children's responses to the four smiley faces from sad to happy were then coded with corresponding values ranging from 1 to 4 . Cronbach's alphas for the averaged mean scores of the two intrinsic value items were $.83, .87$, and .88 for $\mathrm{t} 1$, $\mathrm{t} 2$, and $\mathrm{t} 3$, respectively.

\section{Mathematics Performance}

For assessing children's basic mathematics skills, we used nationally normed ageappropriate mathematics tests LukiMat (Koponen et al., 2011) at the first grade $(M=17.70, S D=$ 3.89), and RMAT (Räsänen, 2004) at the third grade $(M=26.60, S D=4.38)$. As the RMAT is relatively narrow in scope focusing on basic mathematical operations, we also included teacher ratings at the third grade to obtain a more comprehensive assessment of children's mathematics competence. As the children in Finland are not formally graded and no national mathematics tests are used during the first school years, we had the teachers grade each child using the grading scale from 4 (fail) to 10 (excellent) normally applied in Finnish schools in later years ( $M$ $=8.56, S D=0.96)$. 


\section{Analyses}

Latent growth curve modelling (LGCM) within the structural equation modelling framework was used for all analyses (Duncan et al., 1999). In LGCM, repeated measurements of observed variables are used as manifest indicators for the estimation of latent variables representing the two components of a change, initial level (onset of change) and slope (rate of change). The modelling proceeded in four steps: (1) an estimation of univariate LGC models describing change in ability self-concept and intrinsic value separately; (2) an estimation of a parallel process model examining connections between the changes in ability self-concept and intrinsic value; (3) an estimation of a prediction model with gender and first grade mathematics performance as covariates; and (4) an estimation of a full model with third grade mathematics performance and teacher-rated grades as dependent variables. The full model is illustrated in Figure 1.

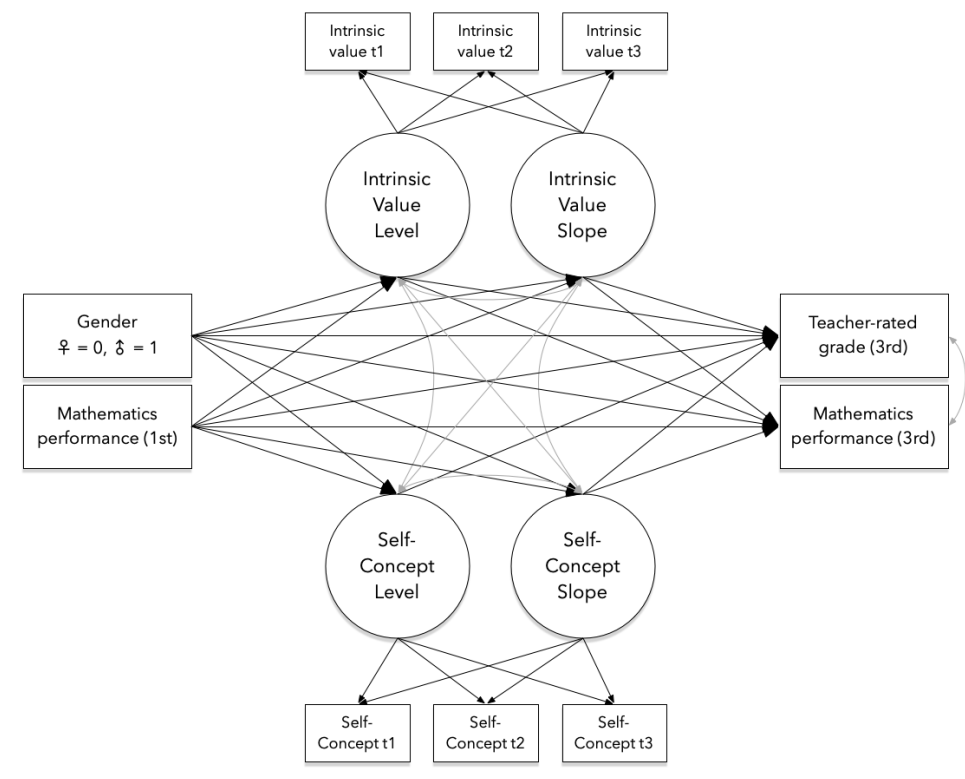

Figure 1. The hypothetical full model tested through a series of latent growth curve models.

To evaluate model fit, we used multiple indices in line with the recommendations by Kline (2016): the Comparative Fit Index (CFI; Bentler, 1990), Root Mean Square Error of Approximation (RMSEA; Steiger, 1990), and Standardized Root Mean Square Residual (SRMR; Hu \& Bentler, 1999) along with the chi-square statistics. For all analyses, maximum likelihood estimation with robust standard errors (MLR) was used, and missing data (Little's MCAR test: $\left.\chi^{2}(257)=244.949, p=.695\right)$ were handled with full-information maximum likelihood method, as implemented in the Mplus 8.6 statistics program (Muthén \& Muthén, 1998-2017). 


\section{Results}

\section{Descriptive Statistics}

As shown in Table 1, the means of mathematics ability self-concept and intrinsic value declined over time, although the overall level was and remained high. Both demonstrated also moderate stability over time, with correlations between measurement points ranging from .33 to .51. Also, mathematics performance showed intraindividual stability over time with a correlation of .47 between the first and third grade mathematics tests. Teacher-rated grade at grade three was strongly linked with third grade mathematics performance.

Table 1. Descriptive statistics and bivariate correlations.

\begin{tabular}{|c|c|c|c|c|c|c|c|c|c|c|c|}
\hline & $M$ & $S D$ & $\begin{array}{c}\text { Self- } \\
\text { concept } \mathrm{t} 1\end{array}$ & $\begin{array}{c}\text { Self- } \\
\text { concept t2 }\end{array}$ & $\begin{array}{c}\text { Self- } \\
\text { concept t3 }\end{array}$ & $\begin{array}{l}\text { Intrinsic } \\
\text { value } \mathrm{t} 1\end{array}$ & $\begin{array}{l}\text { Intrinsic } \\
\text { value } t 2\end{array}$ & $\begin{array}{l}\text { Intrinsic } \\
\text { value } t 3\end{array}$ & $\begin{array}{l}\text { Mathematics } \\
\text { test } 11\end{array}$ & $\begin{array}{l}\text { Mathematics } \\
\text { test } \mathrm{t} 3\end{array}$ & $\begin{array}{l}\text { Teacher } \\
\text { grades } \mathrm{t} 3\end{array}$ \\
\hline Self-concept t1 & 3.60 & 0.58 & - & & & & & & & & \\
\hline Self-concept t 2 & 3.37 & 0.64 & $.38^{* * *}$ & - & & & & & & & \\
\hline Self-concept $\mathrm{t} 3$ & 3.30 & 0.60 & $.36^{* * *}$ & $.51^{* * *}$ & - & & & & & & \\
\hline Intrinsic value $\mathrm{t} 1$ & 3.49 & 0.67 & $.55^{* * *}$ & $.33^{* * *}$ & $.24^{* * *}$ & - & & & & & \\
\hline Intrinsic value $t 2$ & 3.25 & 0.75 & $.37^{* * *}$ & $.59 * * *$ & $.40^{* * *}$ & $.50^{* * *}$ & - & & & & \\
\hline Intrinsic value $\mathrm{t} 3$ & 3.08 & 0.72 & $.23^{* * *}$ & $.30^{* * *}$ & $.48^{* * *}$ & $.34^{* * *}$ & $.58^{* * *}$ & - & & & \\
\hline Mathematics test $\mathrm{t} 1$ & 17.70 & 3.89 & .06 & $.12^{*}$ & $.32^{* * *}$ & .05 & .09 & .08 & - & & \\
\hline Mathematics test $\mathrm{t} 3$ & 26.60 & 5.83 & $.17^{* *}$ & $.18^{* *}$ & $.41^{* * *}$ & $.13^{*}$ & $.16^{* * *}$ & $.26^{* * *}$ & $.47^{* * *}$ & - & \\
\hline Teacher grades $\mathrm{t} 3$ & 8.56 & 0.96 & $.16^{* *}$ & $.17^{* *}$ & $.40^{* * *}$ & $.16^{* *}$ & $.14^{*}$ & $.18^{* *}$ & $.53^{* * *}$ & $.71^{* * *}$ & - \\
\hline Gender & & & .09 & $.18^{* *}$ & $.21^{* * *}$ & .02 & $.20^{* * *}$ & $.13^{*}$ & -.06 & .11 & .01 \\
\hline
\end{tabular}

\section{Changes in Ability Self-Concept and Intrinsic Value}

To address our first research question on changes in ability self-concept and intrinsic value, we estimated two separate growth models. The linear LGC model for ability self-concept resulted in an acceptable fit, $\chi^{2}(1)=6.01, p=.014 ; \mathrm{CFI}=.934 ; \mathrm{RMSEA}=.133(90 \% \mathrm{CI}$ : $.047-.243)$; SRMR $=.029$. The RMSEA was relatively high but given that this is often expected in simple models with small degrees of freedom (Kenny et al., 2015; Shi et al., 2022), and since the other fit indices were acceptable, we proceeded with this model. The negative estimate for slope was significant $(M=-.147, p<.001)$, as were the variances of both the initial level $\left(\mathrm{S}^{2}=.157, p=\right.$ $.001)$ and slope ( $\left.\mathrm{S}^{2}=.045, p=.017\right)$, thus demonstrating an overall decline in mathematics selfconcept and significant individual differences in both the onset and change over time. The fit for the linear model for intrinsic value was excellent, $\chi^{2}(1)=0.938, p=.338$; CFI $=1.000$; RMSEA $=$ .000 (90\% CI: .000-.155); SRMR $=.012$. Again, the negative slope was significant $(M=-.206, p<$ $.001)$ as were the variances of both the initial level $\left(\mathrm{S}^{2}=.332, p<.001\right)$ and slope $\left(\mathrm{S}^{2}=.116, p<\right.$ 
.001). Like ability self-concept, then, students' mathematics intrinsic value showed overall decline yet significant individual differences in the trajectories over time (see Figure 2).

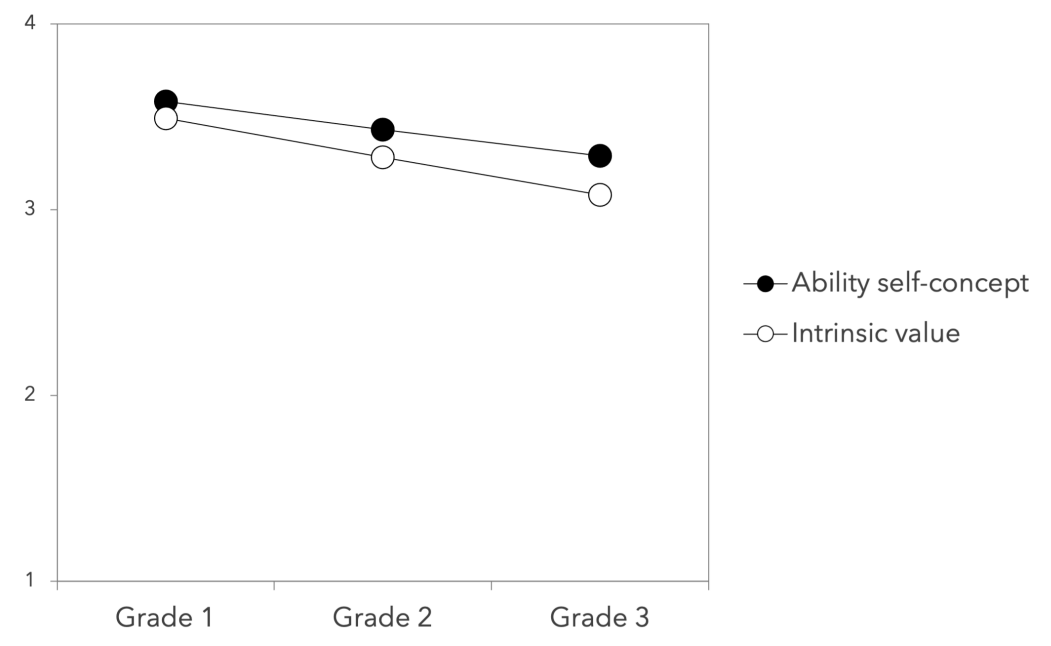

Figure 2. Model estimated means of the developmental trajectories of mathematics ability selfconcept and intrinsic value.

\section{Connections Between the Changes in Ability Self-Concept and Intrinsic Value}

Next, to address our second research question on the connections between changes in ability self-concept and intrinsic value, we estimated a parallel process model where the initial levels and slopes of ability self-concept and intrinsic value were let to correlate. The fit for this multivariate model was not acceptable, $\chi^{2}(7)=47.21, p<.001 ;$ CFI $=.878$; RMSEA $=.142(90 \%$ CI: .105-.182); SRMR = .084. An inspection of the modification indices suggested a significant covariance between time 2 measures of self-concept and intrinsic value. Since this likely reflected some meaningful additional dependency between students' self-evaluations during the second measurement point, we added the given covariance to the model. As the resulting model fit the data well, $\chi^{2}(6)=5.620, p=.467 ; \mathrm{CFI}=1.000$; RMSEA = .000 (90\% CI: .000-.074); SRMR = .024 , and the estimates of change remained virtually identical to those in the previous stage, we decided to proceed with this model. The results (see Table 2) showed strong correlations between both the initial levels $(r=.90, p<.001)$ and slopes $(r=.79, p<.001)$ of self-concept and intrinsic value, meaning that not only were students' mathematics ability self-concept and intrinsic value highly connected already in the first grade, but also the changes in them over time; less negative change in one was linked with less negative change in the other. 
Table 2. Descriptive statistics and latent correlations from the multivariate latent growth model.

\begin{tabular}{|c|c|c|c|c|c|c|c|}
\hline & $M$ & s.e. & $p$ & $\begin{array}{l}\text { Self-concept } \\
\text { Initial level }\end{array}$ & $\begin{array}{l}\text { Self-concept } \\
\text { Slope }\end{array}$ & $\begin{array}{l}\text { Intrinsic value } \\
\text { Initial level }\end{array}$ & $\begin{array}{c}\text { Intrinsic value } \\
\text { Slope }\end{array}$ \\
\hline $\begin{array}{l}\text { Self-concept } \\
\text { Initial level }\end{array}$ & 3.58 & 0.03 & $<.001$ & 1.00 & & & \\
\hline $\begin{array}{l}\text { Self-concept } \\
\text { Slope }\end{array}$ & -0.15 & 0.02 & $<.001$ & -0.25 & 1.00 & & \\
\hline $\begin{array}{l}\text { Intrinsic value } \\
\text { Initial level }\end{array}$ & 3.49 & 0.04 & $<.001$ & $0.90^{* *}$ & $-0.45^{* *}$ & 1.00 & \\
\hline $\begin{array}{l}\text { Intrinsic value } \\
\text { Slope }\end{array}$ & -0.21 & 0.02 & $<.001$ & $-0.44^{* *}$ & $0.79 * *$ & $-0.44^{* *}$ & 1.00 \\
\hline
\end{tabular}

\section{Predictions of Changes in Ability Self-Concept and Intrinsic Value}

In the next steps, we addressed our third research question on the connections between mathematics performance and changes in ability self-concept and intrinsic value by adding predictors and outcomes into the parallel process model. However, the prediction models failed to converge, which might have been due to the high dependencies between the parameters of change in self-concept and intrinsic value. Since this might also be an indication of a higherorder construct underlying the said dependencies, we tested whether a second-order model, a factor-of-curves (FOCUS) model (McArdle, 1988), would capture the trajectories and their joint variation more appropriately (Figure 3).

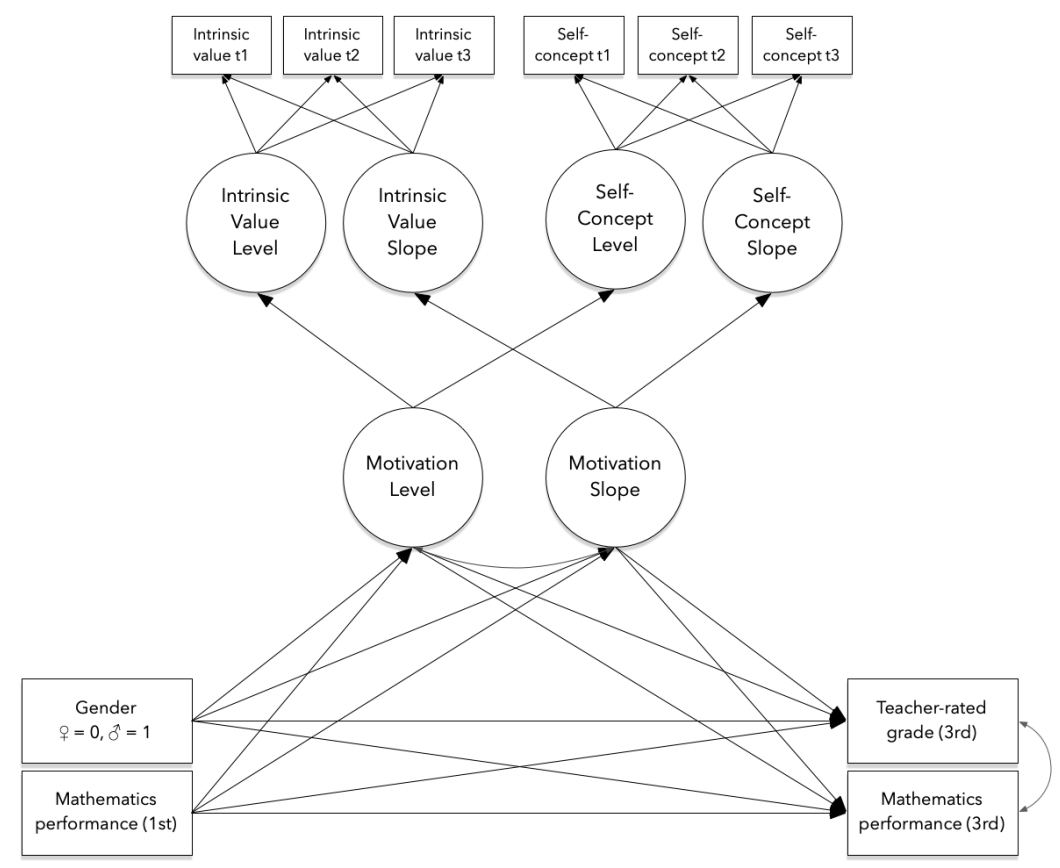

Figure 3. The factor-of-curves model of mathematics motivation with predictors and outcomes. 
In the FOCUS model, we used latent growth factors of ability self-concept and intrinsic value to estimate latent factors representing a common onset and slope, as illustrated in Figure 3 (see, Wickrama et al., 2016). Reflecting the presumed underlying common construct, we refer to this second-order trajectory more generally as "mathematics motivation". The base model fit the data well, $\chi^{2}(10)=12.079, p=.280 ;$ CFI = .994; RMSEA = .027 (90\% CI: .000-.073); SRMR = .049, and showed a significant overall decrease in mathematics motivation $(M=-.200, p<.001)$, as expected. Variances of both initial level $\left(\mathrm{S}^{2}=.191, p<.001\right)$ and change over time $\left(\mathrm{S}^{2}=.071, p<\right.$ .001) were also significant.

Next, we added gender and first grade mathematics test performance as predictors of change in mathematics motivation. The fit of the model was good, $\chi^{2}(18)=34.841, p=.010$; CFI $=.962 ;$ RMSEA $=.057$ (90\% CI: .027-.086); SRMR $=.054$, and the results showed the slope of mathematics motivation to be predicted by both gender $(\beta=.35, p=.013)$ and prior mathematics performance $(\beta=.23, p=.004)$. The positive effect of gender indicated that the negative change in mathematics motivation was less steep for boys.

\section{Predictions of Mathematics Performance}

In the final step, we included third grade mathematics test performance and teacherrated grades as outcomes. This full model fit the data well, $\chi^{2}(26)=42.320, p=.023$; CFI $=.975$; RMSEA $=.047$ (90\% CI: .018-.072); SRMR $=.049$, and showed the test performance and grades to be predicted by both the initial level of mathematics motivation $\left(\beta_{\mathrm{P}}=.34, p<.001\right.$ and $\beta_{\mathrm{G}}=.32$, $\mathrm{p}=.001)$ and the change in it $\left(\beta_{\mathrm{P}}=.36, p<.001\right.$ and $\left.\beta_{\mathrm{G}}=.29, p=.001\right)$. That is, higher initial mathematics motivation and less steep decrease in it over time were both associated with higher mathematics performance and achievement in the third grade. This was true even when controlling for the significant effect of first grade mathematics performance on third grade mathematics performance $(\beta=.36, p<.001)$ and teacher-rated grades $(\beta=.43, p<.001)$. The model explained $34 \%$ and $36 \%$ of the variance in third grade test performance and teacherrated grades, respectively. Significant main effects are illustrated in Figure 4, and all effects reported in Table 3. 


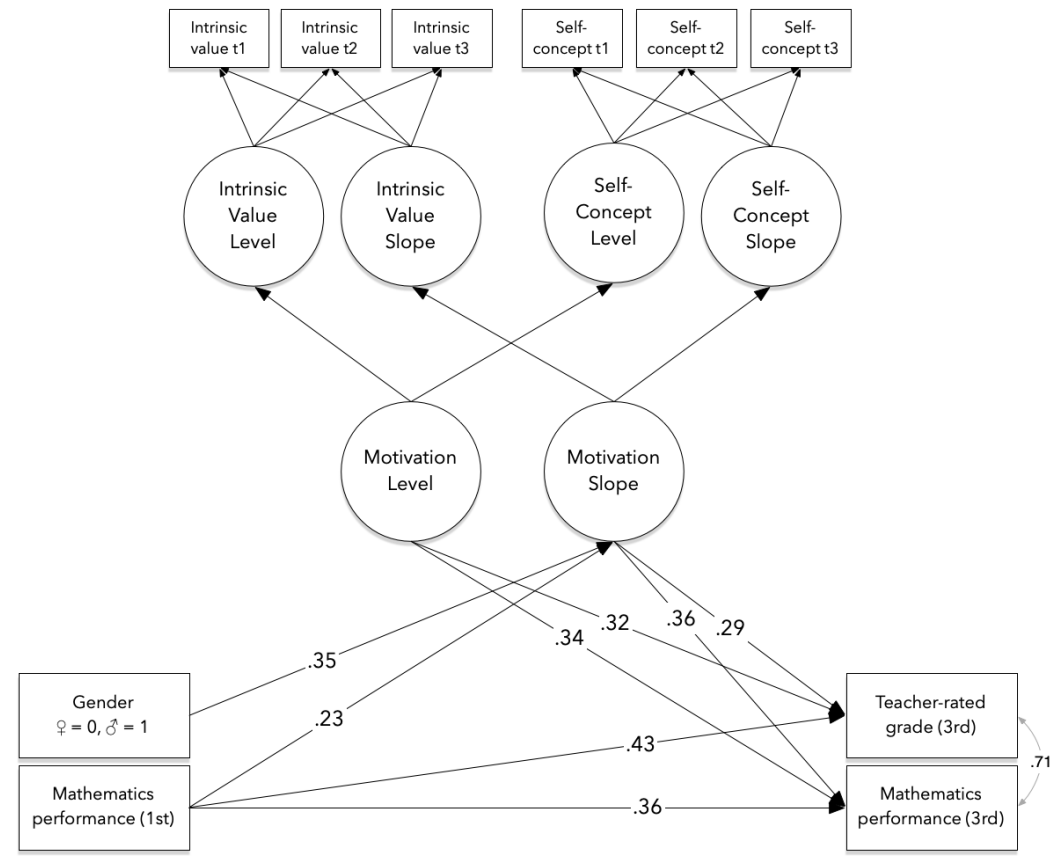

Figure 4. Significant standardised effects from the factor-of-curves model of mathematics motivation with predictors and outcomes.

Table 3. Standardised effects from the full factor-of-curves prediction model.

\begin{tabular}{|c|c|c|c|c|c|c|c|c|c|c|c|c|}
\hline \multirow[b]{2}{*}{ Predictor } & \multicolumn{3}{|c|}{ Motivation: level } & \multicolumn{3}{|c|}{ Motivation: slope } & \multicolumn{3}{|c|}{ Math test $3^{\text {rd }}$} & \multicolumn{3}{|c|}{ Teacher grades $3^{\text {rd }}$} \\
\hline & $\beta$ & $Z$ & $p$ & $\beta$ & $Z$ & $p$ & $\beta$ & $Z$ & $p$ & $\beta$ & $Z$ & $p$ \\
\hline Gender & .22 & 1.54 & .125 & .35 & 2.49 & .013 & .09 & 0.89 & .374 & -.08 & -0.78 & .434 \\
\hline Math test $1^{\text {st }}$ & .10 & 1.31 & .191 & .23 & 2.91 & .004 & .36 & 3.59 & $<.000$ & .43 & 3.78 & $<.000$ \\
\hline Motivation: level & & & & & & & .34 & 4.05 & $<.000$ & .32 & 3.74 & $<.000$ \\
\hline Motivation: slope & & & & & & & .36 & 3.23 & .001 & .29 & 3.26 & .001 \\
\hline
\end{tabular}

\section{Discussion}

This study investigated the developmental interdependence of mathematics ability selfconcept and intrinsic value, and their associations with performance during the first three years of elementary school.

\section{Changes in Ability Self-Concept and Intrinsic Value}

As to our first research question, students' ability self-concept and intrinsic value both declined over time from the initial high level onwards, which concurs with our assumptions and previous studies on similar age groups (Fredricks \& Eccles, 2002; Gaspard et al., 2020; Gottfried 
et al., 2001, 2007; Jacobs et al., 2002; Weidinger et al., 2017). Given the age group, the rank-order stability was relatively high, thus also agreeing with prior research (Spinath \& Steinmayr, 2008; Viljaranta et al., 2014; Weidinger et al., 2018). Importantly, however, significant individual differences both at the onset and subsequent development of students' mathematics motivation were present, meaning that despite the average decline over time, individual trajectories varied. This also has been documented in other studies (Fredricks \& Eccles, 2002; Gottfried et al., 2007; Weidinger et al., 2017), thus reiterating the fact that children may take different developmental paths in their mathematics motivation right from the beginning of formal education.

The observed decline in students' mathematics motivation has mostly been attributed to the developmental changes in children's self-evaluations, the nature of mathematics as a school subject, and changes in the school context (Wigfield \& Cambria, 2010). While the correspondence between perceived and actual attainment is still partly inaccurate (mostly overoptimistic) among the school-beginners, growing cognitive capacity and increasingly heightened sensitivity to social comparisons begins to gradually calibrate competence beliefs (Wigfield \& Eccles, 2000). The increasing focus on performance and assessment over the elementary school years may further underscore this (Boaler, 2016).

\section{Connections Between the Development of Ability Self-Concept and Intrinsic Value}

Regarding the second research question, we found both the initial levels and developmental slopes of ability self-concept and intrinsic value to be strongly correlated. Even to the point that we needed to apply a different modelling approach to the data when including predictors and outcomes. Although this strong dependency may have been partly due to the way ability self-concept and intrinsic value were assessed, it is nevertheless clear that these two aspects of motivation are highly connected, thus supporting our expectations. That is, a more positive view of one's mathematics abilities is linked with how enjoyable the subject is considered, and vice versa, both concurrently and longitudinally. The present data and analyses do not permit any inferences about the causal predominance between ability self-concept and intrinsic value, but most likely their developmental interplay follows a cyclical process, as previously suggested (Marsh et al., 2005; Wigfield \& Eccles, 2000). Future research should pay particular attention to the assessment of school-beginners' motivation to have a better view on whether and how the different facets of children's mathematics motivation become 
differentiated. Perhaps also linking this sort of developmental data with repeated situated measures of daily experiences in the classroom would provide some new insights into how these two facets of motivation contribute to each other.

\section{Predictions of Change in Ability Self-Concept and Intrinsic Value, and Mathematics}

\section{Performance}

Regarding the outcomes, our third question addressed the connections of mathematics performance with changes in mathematics motivation. As mentioned, we had to change our modelling procedure to accommodate the high statistical dependency between the growth parameters of ability self-concept and intrinsic value. Consequently, the applied FOCUS model merged the trajectories of ability self-concept and intrinsic value into higher-order factors representing more general mathematics motivation and change in it. Although this solution loses the differentiated nuances of two qualitatively different aspects of mathematics motivation, it also broadens the scope of our empirical representation of the underlying construct. The findings from this model showed changes in mathematics motivation to be predicted by previous mathematics performance, and to be predictive of later mathematics performance. That is, higher initial mathematics skills were associated with less steep decline in mathematics motivation, which, in turn, was linked with higher subsequent mathematics skills (test performance) and achievement (teacher ratings), even after controlling for the initial mathematics performance. This was in line with our assumptions and concurs with prior studies showing a connection between mathematics motivation and performance (Denissen et al., 2007; Petersen \& Hyde, 2017; Schneider et al., 2018; Weidinger et al., 2018), although fails to make a clear distinction in this regard between ability self-concept and intrinsic value. This is unfortunate, given the different role these two aspects of motivation seem to have in students' educational careers in later years. Even so, it is important to note that from a developmental point of view, the change in students' mathematics motivation already at this age is clearly not independent of their mathematics performance, and more importantly, that positive development in motivation (even in the form of less steep decline over time) influences later performance, above and beyond the effect of previous performance. This supports the view that skills and motivation in mathematics develop in a cyclical manner (Marsh et al., 2005), and that this process begins rather early on (Gottfried et al., 2007). This is particularly notable given the 
fact that school-beginners' views on the subject and their motivational beliefs attached to it are yet only emerging.

\section{Gender Differences}

Finally, a note on gender differences, even though they were not an actual focus of the study. In line with our expectation and previous studies, no gender differences in either mathematics performance or motivation were detected (Tuominen et al., 2021; Viljaranta, Lerkkanen, et al., 2009). In fact, the only gender effect observed was the less negative change in mathematics motivation among boys. These findings seem worthy to be viewed in the given educational context. In Finland, despite the non-existing gender differences on average in mathematics achievement by the end of the comprehensive education, more boys than girls (69 $\%$ vs. $57 \%$ ) choose advanced mathematics courses in the general upper secondary education, and by the end of upper secondary studies, men significantly outperform women (Metsämuuronen, 2013). Gender differences also exist in mathematics-related attitudes and motivation; compared to men, women report experiencing more negative emotions during mathematics classes, and they have less positive mathematics ability self-concept, although no differences are shown on the perceived utility of mathematics.

This means that somewhere along the comprehensive education, developments take place that result in less positive mathematics-related motivational experiences and significantly different choice behaviour among girls, even with no differences in achievement or perceived utility. Based on our findings, these gendered processes are not present when the children first step on their educational paths, but already by the third grade, first indications seem to emerge. To have a more comprehensive view on these developments, extensive longitudinal research would be needed, beginning perhaps already before the formal education, and spanning all the way to upper secondary education and even beyond. It would not be sufficient to just focus on students' achievements and motivations, but also trace their classroom experiences as well as contextual and cultural factors such as instructional strategies and pedagogical processes, and gender stereotypes - not only teachers' and students', but also parents'.

\section{Practical Implications}

Due to the growing complexity and cumulative nature of mathematical competence, the maintenance of positive motivational beliefs almost necessitates a solid foundation of basic 
skills; lacking such foundation may increase doubt in one's abilities, experiences of negative emotions, and diminishing interest (e.g., Pekrun et al., 2017). The decline in motivational beliefs, then, likely reflects not only changes in the educational ethos and age-related calibration processes, but also the growing individual differences in students' mathematical skills and achievements. Consequently, the practical implications for supporting motivation should target both ensuring solid basics skills and implementing everyday classroom activities that diminish social comparison, provide accurate and constructive feedback, and support mastery experiences for all students irrespective of their skill level (e.g., Jansen et al., 2013; Stipek, 2002).

\section{Conclusion}

Taken together, our findings evidence the developmental coupling of students' ability self-concept, intrinsic value, and achievement. Achievement seems to enhance mathematics motivation, and positive motivation appears to support the further development of mathematics skills. This implies that an effective classroom instruction should not only focus on building the foundation of mathematics skills, but also make studying mathematics meaningful and intrinsically rewarding, and support students' confidence while they try to keep up with the challenging subject. Given the significant developmental variation among these young students, particular attention should be paid on those who may be drifting into a negative motivational path already from early on. 


\section{References}

Ahmed, W., van der Werf, G., Kuyper, H., \& Minnaert, A. (2013). Emotions, self-regulated learning, and achievement in mathematics: A growth curve analysis. Journal of Educational Psychology, 105(1), 150-161. https://doi.org/10.1037/a0030160

Arens, A. K., Schmidt, I., \& Preckel, F. (2019). Longitudinal relations among self-concept, intrinsic value, and attainment value across secondary school years in three academic domains. Journal of Educational Psychology, 111(4), 663-684. https://doi.org/10.1037/ edu0000313

Aunola, K., Leskinen, E., \& Nurmi, J.-E. (2006). Developmental dynamics between mathematical performance, task motivation, and teachers' goals during the transition to primary school. British Journal of Educational Psychology, 76(1), 21-40. https://doi.org/ $10.1348 / 000709905 X 51608$

Benden, D. K., \& Lauermann, F. (2022). Students' motivational trajectories and academic success in math-intensive study programs: Why short-term motivational assessments matter. Journal of Educational Psychology, 114(5), 1062-1085. https://doi.org/10.1037/ edu0000708

Bentler, P. M. (1990). Comparative fit indexes in structural models. Psychological Bulletin, 107(2), 238-246. https://doi.org/10.1037/0033-2909.107.2.238

Boaler, J. (2016). Mathematical mindsets: Unleashing students' potential through creative math, inspiring messages, and innovative teaching. Jossey-Bass \& Pfeiffer Imprints.

Bong, M., Cho, C., Ahn, H. S., \& Kim, H. J. (2012). Comparison of Self-Beliefs for Predicting Student Motivation and Achievement. The Journal of Educational Research, 105(5), 336-352. https://doi.org/10.1080/00220671.2011.627401

Denissen, J. J. A., Zarrett, N. R., \& Eccles, J. S. (2007). I Like to Do It, I'm Able, and I Know I Am: Longitudinal Couplings Between Domain-Specific Achievement, Self-Concept, and Interest. Child Development, 78(2), 430-447. https://doi.org/10.1111/ j.1467-8624.2007.01007.x

Duncan, T. E., Duncan, S. C., Strycker, L. A., Li, F., \& Alpert, A. (1999). An introduction to latent variable growth curve modeling: Concepts, issues, and applications. Lawrence Erlbaum Associates Publishers. 
Eccles, J. S., \& Wigfield, A. (1995). In the Mind of the Actor: The Structure of Adolescents' Achievement Task Values and Expectancy-Related Beliefs. Personality and Social Psychology Bulletin, 21(3), 215-225. https://doi.org/10.1177/0146167295213003

Eccles, J. S., \& Wigfield, A. (2020). From expectancy-value theory to situated expectancy-value theory: A developmental, social cognitive, and sociocultural perspective on motivation. Contemporary Educational Psychology, 61, 101859. https://doi.org/10.1016/ j.cedpsych.2020.101859

Eccles, J. S., Wigfield, A., Harold, R. D., \& Blumenfeld, P. (1993). Age and gender differences in children's self- and task perceptions during elementary school. Child Development, 64(3), 830-847. https://doi.org/10.2307/1131221

Fredricks, J. A., \& Eccles, J. S. (2002). Children's competence and value beliefs from childhood through adolescence: Growth trajectories in two male-sex-typed domains. Developmental Psychology, 38(4), 519-533. https://doi.org/10.1037/0012-1649.38.4.519

Frenzel, A. C., Goetz, T., Pekrun, R., \& Watt, H. M. G. (2010). Development of Mathematics Interest in Adolescence: Influences of Gender, Family, and School Context. Journal of Research on Adolescence, 20(2), 507-537. https://doi.org/10.1111/j.1532-7795.2010.00645.x

Ganley, C. M., \& Lubienski, S. T. (2016). Mathematics confidence, interest, and performance: Examining gender patterns and reciprocal relations. Learning and Individual Differences, 47, 182-193. https://doi.org/10.1016/j.lindif.2016.01.002

Garon-Carrier, G., Boivin, M., Guay, F., Kovas, Y., Dionne, G., Lemelin, J., Séguin, J. R., Vitaro, F., \& Tremblay, R. E. (2016). Intrinsic Motivation and Achievement in Mathematics in Elementary School: A Longitudinal Investigation of Their Association. Child Development, 87(1), 165-175. https://doi.org/10.1111/cdev.12458

Gaspard, H., Lauermann, F., Rose, N., Wigfield, A., \& Eccles, J. S. (2020). Cross-Domain Trajectories of Students' Ability Self-Concepts and Intrinsic Values in Math and Language Arts. Child Development, 91(5), 1800-1818. https://doi.org/10.1111/cdev.13343

Gottfried, A. E. (1990). Academic intrinsic motivation in young elementary school children. Journal of Educational Psychology, 82(3), 525-538. https://doi.org/ 10.1037/0022-0663.82.3.525

Gottfried, A. E., Fleming, J. S., \& Gottfried, A. W. (2001). Continuity of academic intrinsic 
motivation from childhood through late adolescence: A longitudinal study. Journal of Educational Psychology, 93(1), 3-13. https://doi.org/10.1037/0022-0663.93.1.3

Gottfried, A. E., Marcoulides, G. A., Gottfried, A. W., \& Oliver, P. H. (2013). Longitudinal pathways from math intrinsic motivation and achievement to math course accomplishments and educational attainment. Journal of Research on Educational Effectiveness, 6(1), 68-92. https://doi.org/10.1080/19345747.2012.698376

Gottfried, A. E., Marcoulides, G. A., Gottfried, A. W., Oliver, P. H., \& Guerin, D. W. (2007). Multivariate latent change modeling of developmental decline in academic intrinsic math motivation and achievement: Childhood through adolescence. International Journal of Behavioral Development, 31(4), 317-327. https://doi.org/10.1177/0165025407077752

Helmke, A., \& van Aken, M. A. G. (1995). The causal ordering of academic achievement and selfconcept of ability during elementary school: A longitudinal study. Journal of Educational Psychology, 87(4), 624-637. https://doi.org/10.1037/0022-0663.87.4.624

Herbert, J., \& Stipek, D. (2005). The emergence of gender differences in children's perceptions of their academic competence. Journal of Applied Developmental Psychology, 26(3), 276295. https://doi.org/10.1016/j.appdev.2005.02.007

Hu, L., \& Bentler, P. M. (1999). Cutoff criteria for fit indexes in covariance structure analysis: Conventional criteria versus new alternatives. Structural Equation Modeling: A Multidisciplinary Journal, 6(1), 1-55. https://doi.org/10.1080/10705519909540118

Jacobs, J. E., Lanza, S., Osgood, D. W., Eccles, J. S., \& Wigfield, A. (2002). Changes in Children's SelfCompetence and Values: Gender and Domain Differences across Grades One through Twelve. Child Development, 73(2), 509-527. https://doi.org/10.1111/1467-8624.00421

Jansen, B. R. J., Louwerse, J., Straatemeier, M., Van der Ven, S. H. G., Klinkenberg, S., \& Van der Maas, H. L. J. (2013). The influence of experiencing success in math on math anxiety, perceived math competence, and math performance. Learning and Individual Differences, 24,190-197. https://doi.org/10.1016/j.lindif.2012.12.014

Kenny, D. A., Kaniskan, B., \& McCoach, D. B. (2015). The Performance of RMSEA in Models With Small Degrees of Freedom. Sociological Methods \& Research, 44(3), 486-507. https:// doi.org/10.1177/0049124114543236

Kline, R. B. (2016). Principles and practice of structural equation modeling (4th ed.). Guilford 
publications.

Koponen, T., Salminen, J., Aunio, P., \& Polet, J. (2011). LukiMat—Oppimisen arviointi: Matematiikan tuen tarpeen tunnistamisen välineet 1. Luokalle. Käyttäjän opas.

Lauermann, F., Tsai, Y.-M., \& Eccles, J. S. (2017). Math-related career aspirations and choices within Eccles et al.'s expectancy-value theory of achievement-related behaviors. Developmental Psychology, 53(8), 1540-1559. https://doi.org/10.1037/dev0000367

Lazarides, R., Viljaranta, J., Aunola, K., \& Nurmi, J.-E. (2018). Teacher ability evaluation and changes in elementary student profiles of motivation and performance in mathematics. Learning and Individual Differences, 67, 245-258. https://doi.org/10.1016/ j.lindif.2018.08.010

Lee, H., \& Kim, Y. (2014). Korean adolescents' longitudinal change of intrinsic motivation in learning English and mathematics during secondary school years: Focusing on gender difference and school characteristics. Learning and Individual Differences, 36, 131-139. https://doi.org/10.1016/j.lindif.2014.07.018

Marsh, H. W., Pekrun, R., Parker, P. D., Murayama, K., Guo, J., Dicke, T., \& Arens, A. K. (2019). The murky distinction between self-concept and self-efficacy: Beware of lurking jingle-jangle fallacies. Journal of Educational Psychology, 111(2), 331-353. https://doi.org/10.1037/ edu0000281

Marsh, H. W., Trautwein, U., Lüdtke, O., Köller, O., \& Baumert, J. (2005). Academic Self-Concept, Interest, Grades, and Standardized Test Scores: Reciprocal Effects Models of Causal Ordering. Child Development, 76(2), 397-416. https://doi.org/10.1111/ j.1467-8624.2005.00853.x

McArdle, J. J. (1988). Dynamic but Structural Equation Modeling of Repeated Measures Data. In J. R. Nesselroade \& R. B. Cattell (Eds.), Handbook of Multivariate Experimental Psychology (pp. 561-614). Springer US. https://doi.org/10.1007/978-1-4613-0893-5_17

Metsämuuronen, J. (2013). Perusopetuksen matematiikan oppimistulosten pitkittäisarviointi vuosina 2005-2012 [Longitudinal evaluation of learning outcomes in mathematics in compulsory education in 2005-2012] (2013:4). Finnish National Agency for Education. https://karvi.fi/app/uploads/2014/09/OPH-0113.pdf

Musu-Gillette, L. E., Wigfield, A., Harring, J. R., \& Eccles, J. S. (2015). Trajectories of change in 
students' self-concepts of ability and values in math and college major choice. Educational Research and Evaluation, 21(4), 343-370. https://doi.org/ $10.1080 / 13803611.2015 .1057161$

Muthén, L. K., \& Muthén, B. O. (1998-2017). Mplus User's Guide (8th ed.). Muthén \& Muthén. Niemivirta, M., \& Tapola, A. (2007). Self-Efficacy, Interest, and Task Performance: Within-Task Changes, Mutual Relationships, and Predictive Effects. Zeitschrift für Pädagogische Psychologie, 21(3/4), 241-250. https://doi.org/10.1024/1010-0652.21.3.241

Nuutila, K., Tapola, A., Tuominen, H., Molnár, G., \& Niemivirta, M. (2021). Mutual relationships between the levels of and changes in interest, self-efficacy, and perceived difficulty during task engagement. Learning and Individual Differences, 92, 102090. https:// doi.org/10.1016/j.lindif.2021.102090

OECD. (2019). PISA 2018 Results (Volume I): What students know and can do. PISA, OECD. https:// doi.org/10.1787/5f07c754-en

Pekrun, R., Lichtenfeld, S., Marsh, H. W., Murayama, K., \& Goetz, T. (2017). Achievement Emotions and Academic Performance: Longitudinal Models of Reciprocal Effects. Child Development, 88(5), 1653-1670. https://doi.org/10.1111/cdev.12704

Petersen, J. L., \& Hyde, J. S. (2017). Trajectories of self-perceived math ability, utility value and interest across middle school as predictors of high school math performance. Educational Psychology, 37(4), 438-456. https://doi.org/10.1080/01443410.2015.1076765

Pinxten, M., Marsh, H. W., De Fraine, B., Van Den Noortgate, W., \& Van Damme, J. (2014). Enjoying mathematics or feeling competent in mathematics? Reciprocal effects on mathematics achievement and perceived math effort expenditure. British Journal of Educational Psychology, 84(1), 152-174. https://doi.org/10.1111/bjep.12028

Räsänen, P. (2004). RMAT - Laskutaidon testi 9-12-vuotiaille. Niilo Mäki Instituutti.

Schneider, R., Lotz, C., \& Sparfeldt, J. R. (2018). Smart, confident, interested: Contributions of intelligence, self-concept, and interest to elementary school achievement. Learning and Individual Differences, 62, 23-35. https://doi.org/10.1016/j.lindif.2018.01.003

Schukajlow, S., Rakoczy, K., \& Pekrun, R. (2017). Emotions and motivation in mathematics education: Theoretical considerations and empirical contributions. ZDM - Mathematics Education, 49(3), 307-322. https://doi.org/10.1007/s11858-017-0864-6 
Shi, D., DiStefano, C., Maydeu-Olivares, A., \& Lee, T. (2022). Evaluating SEM Model Fit with Small Degrees of Freedom. Multivariate Behavioral Research, 57(2-3), 179-207. https:// doi.org/10.1080/00273171.2020.1868965

Simpkins, S. D., Davis-Kean, P. E., \& Eccles, J. S. (2006). Math and science motivation: A longitudinal examination of the links between choices and beliefs. Developmental Psychology, 42(1), 70-83. https://doi.org/10.1037/0012-1649.42.1.70

Spinath, B., \& Steinmayr, R. (2008). Longitudinal Analysis of Intrinsic Motivation and Competence Beliefs: Is There a Relation Over Time? Child Development, 79(5), 15551569. https://doi.org/10.1111/j.1467-8624.2008.01205.x

Spinath, B., \& Steinmayr, R. (2012). The Roles of Competence Beliefs and Goal Orientations for Change in Intrinsic Motivation. Journal of Educational Psychology, 104(4), 1135-1148. https://doi.org/10.1037/a0028115

Steiger, J. H. (1990). Structural Model Evaluation and Modification: An Interval Estimation Approach. Multivariate Behavioral Research, 25(2), 173-180. https://doi.org/10.1207/ s15327906mbr2502_4

Stipek, D. J. (2002). Motivation to learn: Integrating theory and practice (4th ed). Allyn and Bacon.

Stipek, D. J., \& Iver, D. M. (1989). Developmental Change in Children's Assessment of Intellectual Competence. Child Development, 60(3), 521-538. https://doi.org/10.2307/1130719

Trautwein, U., Marsh, H. W., Nagengast, B., Lüdtke, O., Nagy, G., \& Jonkmann, K. (2012). Probing for the multiplicative term in modern expectancy-value theory: A latent interaction modeling study. Journal of Educational Psychology, 104(3), 763-777. https://doi.org/ $10.1037 / \mathrm{a} 0027470$

Tuominen, H., Niemivirta, M., Korhonen, J., Tapola, A., \& Mononen, R. (2021). Matemaattisten taitojen ja motivaation profiilit ensimmäisen luokan oppilailla [Profiles of mathematical skills and motivation among first grade students]. Psykologia, 56(6), 548-566.

Viljaranta, J., Lerkkanen, M.-K., Poikkeus, A.-M., Aunola, K., \& Nurmi, J.-E. (2009). Cross-lagged relations between task motivation and performance in arithmetic and literacy in kindergarten. Learning and Instruction, 19(4), 335-344. https://doi.org/10.1016/ j.learninstruc.2008.06.011

Viljaranta, J., Nurmi, J.-E., Aunola, K., \& Salmela-Aro, K. (2009). The role of task values in 
adolescents' educational tracks: A person-oriented approach. Journal of Research on Adolescence, 19(4), 786-798. https://doi.org/10.1111/j.1532-7795.2009.00619.x

Viljaranta, J., Tolvanen, A., Aunola, K., \& Nurmi, J.-E. (2014). The Developmental Dynamics between Interest, Self-concept of Ability, and Academic Performance. Scandinavian Journal of Educational Research, 58(6), 734-756. https://doi.org/ $10.1080 / 00313831.2014 .904419$

Watt, H. M. G. (2006). The role of motivation in gendered educational and occupational trajectories related to maths. Educational Research and Evaluation, 12(4), 305-322. https://doi.org/10.1080/13803610600765562

Watt, H. M. G., Shapka, J. D., Morris, Z. A., Durik, A. M., Keating, D. P., \& Eccles, J. S. (2012). Gendered motivational processes affecting high school mathematics participation, educational aspirations, and career plans: A comparison of samples from Australia, Canada, and the United States. Developmental Psychology, 48(6), 1594-1611. https:// doi.org/10.1037/a0027838

Weidinger, A. F., Steinmayr, R., \& Spinath, B. (2017). Math grades and intrinsic motivation in elementary school: A longitudinal investigation of their association. British Journal of Educational Psychology, 87(2), 187-204. https://doi.org/10.1111/bjep.12143

Weidinger, A. F., Steinmayr, R., \& Spinath, B. (2018). Changes in the Relation Between Competence Beliefs and Achievement in Math Across Elementary School Years. Child Development, 89(2), e138-e156. https://doi.org/10.1111/cdev.12806

Wickrama, K., Lee, T. K., O’Neal, C. W., \& Lorenz, F. (2016). Higher-order growth curves and mixture modeling with Mplus: A practical guide. Routledge.

Wigfield, A. (1994). Expectancy-value theory of achievement motivation: A developmental perspective. Educational Psychology Review, 6(1), 49-78. https://doi.org/10.1007/ BF02209024

Wigfield, A., \& Cambria, J. (2010). Students' achievement values, goal orientations, and interest: Definitions, development, and relations to achievement outcomes. Developmental Review, 30(1), 1-35. https://doi.org/10.1016/j.dr.2009.12.001

Wigfield, A., \& Eccles, J. S. (2000). Expectancy-Value Theory of Achievement Motivation. Contemporary Educational Psychology, 25(1), 68-81. https://doi.org/10.1006/ 
ceps.1999.1015

Wigfield, A., Tonks, S. M., \& Klauda, S. L. (2016). Expectancy-Value Theory. In K. R. Wentzel \& D. B. Miele (Eds.), Handbook of motivation at school (2nd ed., pp. 55-74). Routledge. https:// doi.org/10.4324/9781315773384.ch4

$\mathrm{Xu}$, J. (2018). Reciprocal effects of homework self-concept, interest, effort, and math achievement. Contemporary Educational Psychology, 55, 42-52. https://doi.org/ 10.1016/j.cedpsych.2018.09.002 
APPENDIX

How much do you like mathematics?

How good you think you are in mathematics?

How much do you enjoy being in math classes?

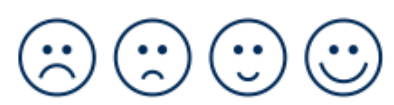

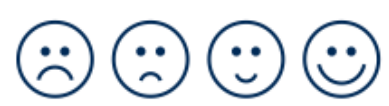

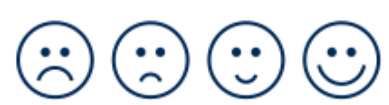

